\title{
蛍光 X線分析顕微鏡を用いたチャの無機元素分析.
}

\author{
静岡県茶業試験場*1 \\ 佐田康稔 ${ }^{* 2}$ ・西島卓也*3 - 森田明雄*4 \\ 独立行政法人 食品総合研究所*5 \\ 重山畺由美 \\ (平成13年12月19日受理)
}

\section{Analysis of Inorganic Elements in Tea Leaves by the X-Ray Fluorescence Microscope Analyzer}

\author{
Yasutoshi SADA, Takuya NishiJIMA, Akio Morita \\ Shizuoka Tea Experiment Station \\ Mayumi OHNISHI-KAMEYAMA \\ National Food Research Institute
}

\section{Summary}

Inorganic elements in tea leaves (Camellia sinensis cv. Yabukita) were investigated using an X-ray fluorescence (XRF) microscope analyzer. The pixcel-intensitities from XRF images of potassium in new buds were higher than those in mature or immature leaves. The calcium content was higher in mature leaves than in immature leaves, especially in petiol.

The distribution of the inorganic elements was changed by the infection of tea anthracnose (Colletotrichum theae-sinensis (MIYAKE) YAMAMOTO). While calcium was accumulated at the lesion point, potassium was decreased as the progress of disease.

XRF microscope analyzer lead to simple, nondestructive and simultaneous element analysis in tea leaves. It will be useful for elucidation of response mechanism for physiological disorder or damage by disease and pest based on elements dynamics.

$\begin{array}{lll}\text { 緒 } & \text { 素であり, 久乏や過剩によって生育障害が起 } \\ & \text { こるなど植物生育にとって不可欠な成分であ }\end{array}$ 無機元素は植物の物質代謝に必要な構成元線マッピング装置 $(\mathrm{XE}$

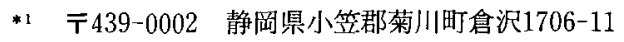

*2 現 静岡県静岡工業技術センター

*3 現 静岡県農林大学校茶業分校

*4 現 静岡大学農学部

*5 =305-8642 茨城県つくば市観音台2-1-12 
MS）を用いて，ストレスなどの異常障害部 の元素移行などをイネの葉身においてモニタ リングしている。それによると, 植物が組織 回復できないほどのストレスや障害を受けた 場合, 初めにカリウムが障害部から他の組織 へ移行し, 障害を受けた表皮下の組織が過大 な酸化状態になって，カルシウムがこの部分 に集積する。次いでマンガンが蒸散流によっ て障害部へ集積することを明らかにしてい る。チャについては, 石垣 ${ }^{3}$ がX線マイクロア ナライザーを用いて，マンガン過剩症による 異常斑点部の障害要因を解析している。

チャは,他の植物に比べて,マンガンやフッ 素, アルミニウムなどの無機元素を比較的多 く含む。その中で, マンガンは施与量の増加 とともに窒素含有率が漸次減少し, 良質な茶 ほどマンガン含有量が少ない4。茶葉中のマ ンガン含有量は茶芽の部位によって異なり, 下位葉に多く含まれる, ${ }^{5,6)}$ 。フッ素とアルミニ ウムの含有量には高い相関があり，新葉に少 なく, 古葉に多い ${ }^{4,7}$ 。また, チャの生育に大 きく影響しているアルミニウムは，苦渋味成 分であるカテキン類と錯体を形成した状態で 存在していると推定されていることな ど7,8), チャにおいては無機元素が生育のみな らず，品質にも大きく影響していると考えら れ, その動態を知ることは茶生産に重要であ る。

一般に，無機元素の分析には原子吸光法や 炎光法, プラズマ発光分光法等が用いられて いる9。プラズマ発光分光法は高感度で多元 素同時分析が可能であるという利点があり, 茶の標準的な分析法としてもあげられている ものの，いずれの分析方法においても煩雑な 前処理が必要になる。

これに対して, 蛍光 $\mathrm{X}$ 線分析顕微鏡(以下, X R F 分析) は上記の元素検出法に比べて感 度が低い，あるいは生体試料では測定面が平 坦・平滑ではないと撖密な定量を行うことが できないという短所はあるが，抽出や固定化 などの前処理を必要とせず, 非破壊で多元素 同時分析が可能であるという長所がある。ま た, X R F 分析は植物生体中の無機成分を大
気圧下で二次元走査することができるため， チャの生育や生理障害など茶葉中の無機元素 動態を知るうえで有用な方法と考えられる。 しかしながら, 可搬型や携带型のX R F 分析 装置は開発されておらず，永年作物である チャを植栽された状態のまま測定するのは困 難である。

そこで，採取した茶葉を殺青処理および凍 結乾燥処理をした茶葉について, 非破壊でよ り簡便な X R F 分析による無機元素分析法を 検討するとともに, チャ炭疽病に罹病し, 病 斑が拡大していく茶葉を経時的に採取し，そ の無機元素動態をX R F 分析法で調查した。

\section{2 実 験 方. 法}

\section{1 茶葉試料の調製}

殺青葉は静岡県茶業試験場温室内でペー パーポット育苗した‘やぶきた'1年生苗の成 葉, 新葉, 心を2000年3月22日に採取し, 電子 レンジで 1 分間殺青した後, 直ちにX R F 分 析を行った。凍結乾燥葉は，同様に殺青し， 凍結乾燥処理をした後にX R F 分析を行っ た。

\section{2 炭疽病䍜病葉の調製}

供試したチャ炭疽病菌は1990年5月富士市 石坂の静岡県茶業試験場富士分場内のやや゙ きた’樹に自然発生した病葉から常法により 単胞子分離し、継代保存している菌株を用い た。供試菌株は茶葉培地を用い $25^{\circ} \mathrm{Cで}$ 約 1 ケ 月培養後、形成された分生子を極少量の Tween20を添加した脱塩水に懸濁し、107個/ $\mathrm{m} l$ レベルの調製した分生子懸濁液を接種源 とした。

二番茶生育期の1999年 6 月21日の降雨中 に，この懸濁液約 $150 \mathrm{~m} l / \mathrm{m}^{2}$ ‘やぶきた’茶株 面に電動式噴霧器を用いて噴霧接種した。炭 疽病病斑は接種から12日後に初発生を確認し た。その後, 炭疽病の各病斑ステージにあわ せて，接種から15日，17日，19日，22日，29 日後に第 $2 \sim 4$ 葉位の雀病葉（成熟した二番 茶の新葉）を採取し，直ちに電子レンジで殺 青後, 凍結乾燥処理し, 分析まで $0{ }^{\circ} \mathrm{Cで}$ 冷凍 保管した。 


\section{3 䖺光 X線分析䫓微鏡の測定条件}

蛍光 $X$ 線分析䫓微鏡 $\mathrm{X} \mathrm{G} \mathrm{T}-2000 \mathrm{~V}$ (堀場 製作所製）を用いて，XR F 分析を行った。 測定条件は，X線ビームスポット： $\phi 100 \mu$ $\mathrm{m}, \mathrm{X}$ 線ターゲット：ロジウム $(\mathrm{Rh})$, 管電 圧：50keV, 管電流： $1 \mathrm{~mA}$, 検出:Si検出器, スキャン速度：1200秒 / scan, 積算回数：36 回，マッピング画素数： $256 \times 256$ ピクセルと した。

X R F 分析は蕨密な定量を行うために測定 面を平坦・平滑にする必要がある。そこで, 茶葉試料は試料上面を平らにし，水の蒸散に よる形状変化を防ぐため, 市販の家庭用ポリ エチレンフィルムで被覆した。また、凍結乾 燥茶葉は試料表面を平らにするため，分析前 にイオン交換水を含水させ,同様に測定した。 炭疽病䍜病葉の凍結乾燥試料も同様に含水, 被覆後に測定した。

\section{3 実験結果および考察}

\section{1 茶葉中の無機元素}

殺青後の成葉および新葉，心の各部分の蛍 光X線スペクトルを測定し, $\mathrm{X}$ 線透過像とカ リウム, カルシウム, リン, マンガン, 鉄に ついて画像化した (図 1)。各元素のマッピン グ画像は白色の濃い部分により多くの元素が 分布していることを表す。その結果，カリウ 么 (図 1 (B)) は成葉, 新葉の全体に存在し, 心にやや多くみられた。また，カルシウム（図 $1(\mathrm{C}))$ 注成葉や硬化が始まった新葉に多く， 特に葉柄に多く存在していた。リン（図 1

(D)) は生育段階にかかわらず，成葉，新葉 全体に分布していた。マンガン（図1 (E)) は成葉と硬化した新葉の周縁部に多く存在し ていた。鉄（図1（F））はマッピング画像で その存在部位を確認することはできなかっ た。

凍結乾燥処理後の茶葉についても殺青葉と 同様に，X線透過像と各成分の画像化を行っ た(図 2)。殺青葉と同様,カリウム(図 $2(\mathrm{~B})$ ) は成葉, 新葉全体に, カルシウム (図 $2(\mathrm{C})$ ) は成葉，特に葉柄に多くみられた。リン（図 2 (D)) は成葉, 新葉全体に分布し, マンガ
ン（図 $2(\mathrm{E}))$, 鉄（図 2（F)）吅成葉全体 に分布していた。リンは殺青葉に比べて凍結 乾燥葉でやや明瞭に確認することができた が，殺青葉と凍結乾燥葉の画像を比較してみ ると,両者の分布に顕著な差異は認められず, 乾燥や分析時のイオン交換水含水処理などの 前処理操作の違いで元素の分布状態が变わる ことはないと考えられた。

茶葉中の無機成分含有量は上位葉ほどリン 酸, カリウムが多く,カルシウム, マンガン, 鉄などは逆に硬化した下位葉に多いとされ $3^{5,6)}$ 。殺青葉と凍結乾燥葉のマッピング画像 （図 1，2）をみると, カリウム,リンは新 葉，心に確認できるが，カルシウム，マンガ ン，鉄は成葉のみで認められ，新葉や心では 確認できない。マッピング画像の各元素分布 は部位別含有量 ${ }^{5,6)}$ と同様の傾向を示してお り, X R F 分析は茶葉中の元素の分布や動態 が解析できると考えられた。

図 3 に殺青葉分析時の蛍光 $\mathrm{X}$ 線スペクトル を示した。図中に記したように，蛍光X線ス ペクトルはカリウム，カルシウムのほかに， 硫黄, アルミニウムなどの微量元素が認めら れたが，これらの元素は分布する部位をマッ ピング画像で確認することはできなかった。 このことから，これらの元素は特定の部位に 局在しているのではなく, 茶葉全体に広く分 布していることが示唆された。

このように，カリウム，カルシウムなどの 含有量の比較的多い無機元素であれば，X R $\mathrm{F}$ 分析によって, 局所への移行, 茶葉内の動 態を多元素同時に把握することが可能と考え られた。また，電子レンジによる殺青処理を した茶葉, 凍結乾燥茶葉など, 茶葉の処理形 態にかかわらず分析ができるものと考えられ た。一般の化学分析では, 局所の無機元素を 分析することは難しいが，XＲＦ分析は茶葉 の無機元素の動態が把握できる有用な方法と 考えられた。

3.2 チャ炭疽病壊死病斑の拡大と無機元素 の動態

炭瘟病菌㲘濁液接種後 15日～29日後の病斑 を図 4 (A) に示す。病斑は接種15日後に葉 


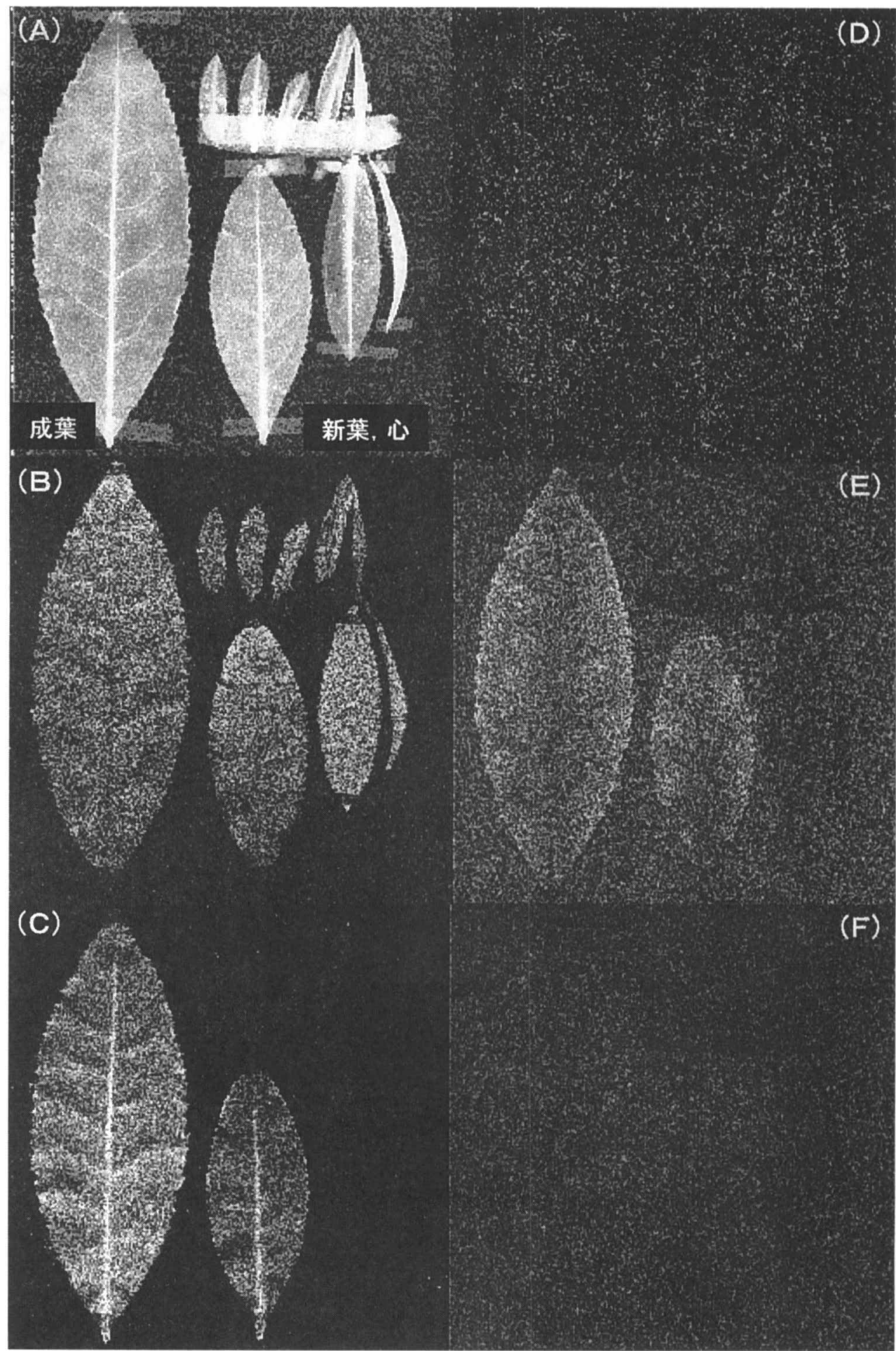

図 1 蛍光 X 線分析顕微鏡マッピング画像による茶殺青葉の元素分布

(A) X 線透過像 (B)カリウムの蛍光X線マッピング画像 (C)カルシウムのマッピング画像 (D) リンのマッピング画像 (E)マンガンのマッピング画像 (F)鉄のマッピング画像 *各マッピング画像は白色の濃い部分により多くの元素が分布していることを表す。 
(茶研報93：47～54, 2002)

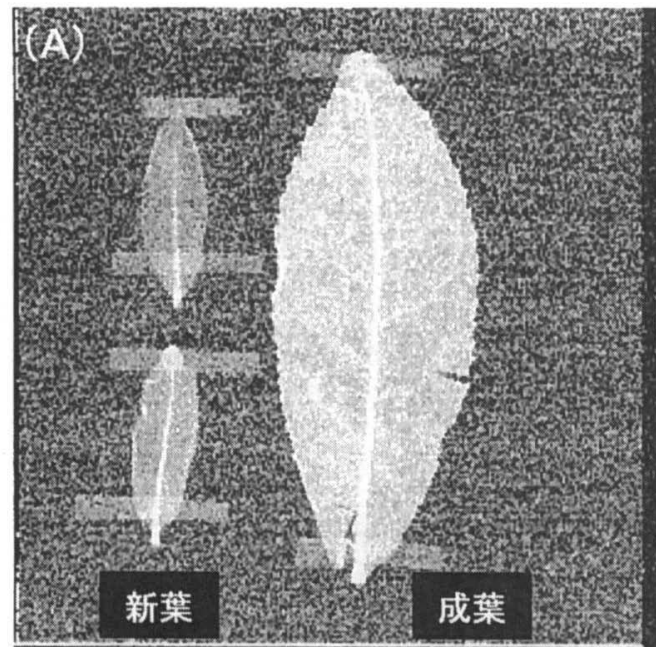

(D)
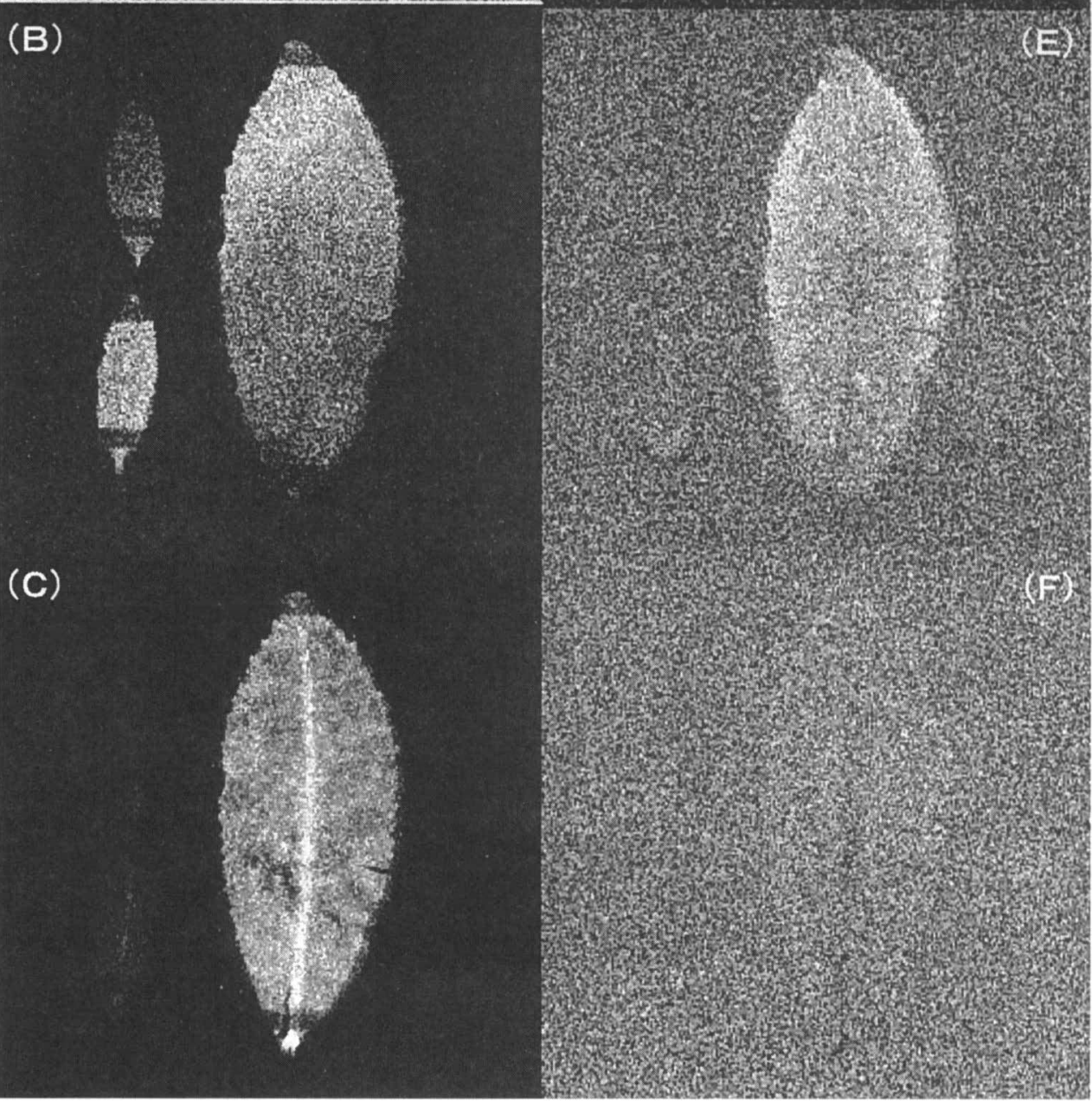

図 2 蛍光 X 線分析顕微鏡マッピング画像による凍結乾燥茶葉の元素分布

(A) X 線透過像 (B) カリウムの営光X線マッピング画像 (C) カルシウムのマッピング画像

(D) リンのマッピング画像 (E) マンガンのマッピング画像 (F)鉄のマッピング画像

*各マッピング画像は白色の濃い部分により多くの元素が分布していることを表す。 


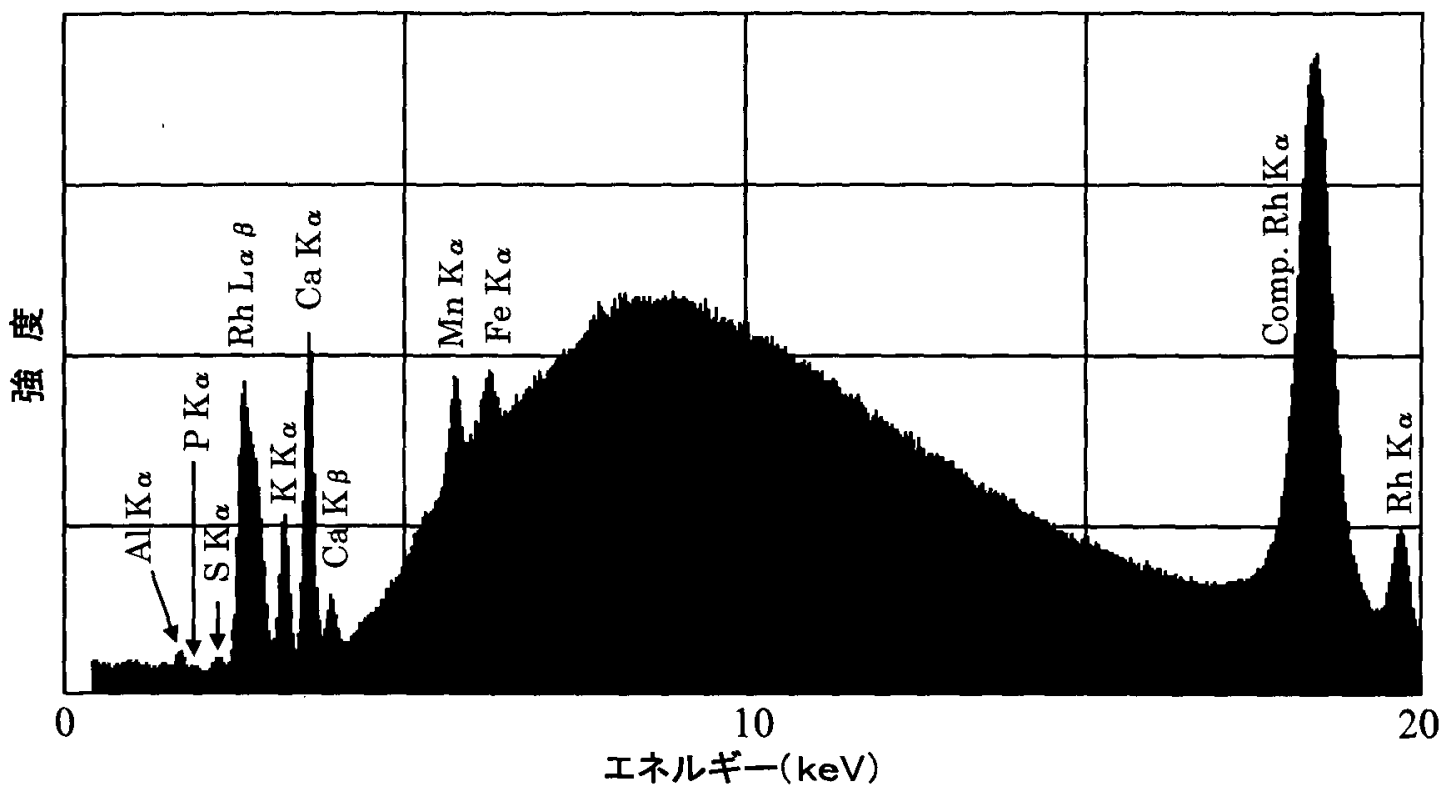

図 3 蛍光 X線顕微鏡による茶殺青葉の监光 X線スペクトル * 図中の $\mathrm{K} \alpha, \mathrm{K} \beta, \mathrm{L} \alpha \beta$ はそれぞれ $\mathrm{K}$ 系列，L系列のスペクトルを表す。

脈部に，17日後には壊死が周縁の葉肉部に拡 大し，明瞭な炭疽病病斑となった。また，接 種22２9日後には典型的な炭疽病の大型壤死 病斑が形成され，X線透過像でも病斑部が黒 く写し出され，明瞭にとらえることができた

(図 4 (B))。

炭疽病壊死病斑の拡大によるカリウムの動 態を図 4 (C) に，カルシウムの動態を図 4

（D）に示した。葉脈周辺に壊死が拢大する 接種17日後, 茶葉全体が白く, カリウム, カ ルシウムが茶葉全体に分布していたが，その 後, 壊死の拡大とともに壊死病斑部が徐々に 黒くなり，カリウムが消失していた（図4

(C)）。逆に，カルシウムは病斑部の白色が 濃くなり，カルシウムが病斑部に蓄積してい く様子が認められた（図４（D））。マンガン は, 接種29日後の炭瘨病䍜病葉において, 他 の部位よりも壊死病斑部に白い点がやや多く みられた程度であり，その動態は判然としな かった (図 4 (E))。

また，鉄，硫黄およびその他の元素をマッ ピング画像化したが，いずれの元素も炭疽病 の壊死病斑部に局在するような動態は認めら れなかった。
一般に, 植物は過度のストレスを受けると 葉にクロロシス (黄化) やネクロシス (壊死) 症状を発現することが多い。すでに緒言で述 ベたように，イネでは障害部分に扔けるカり ウムの消失, カルシウム, マンガンの集積が 知られているが, チャ炭疽病罹病葉の場合, カリウム, カルシウムは同様の傾向を示した が，マンガンの集積は認められなかった。

一方, 炭瘨病菌が茶葉に侵入した場合, 宿 主の抵抗反応として，その部位の細胞壁が部 分的に肥厚して菌の侵入を阻止することが報

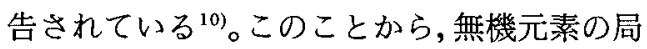
所への䔟行が炭瘨病菌の侵入に対して何らか の役割を果たしている可能性も考えられた。 しかし, 無機元素の移行はストレスや壊死に よって起きるといわれており, 茶葉中のカリ ウム, カルシウムの動態が炭瘨病菌の侵入に 対する反応であるのかどうかについては今回 の実験からは明らかとならなかった。今後, 他の病害における無機元素の移行を調查する ことによって, 無機元素の局在と病害に対す る茶樹の反応の関係解明につながるものと期 待される。 
(茶研報93：47～54, 2002)

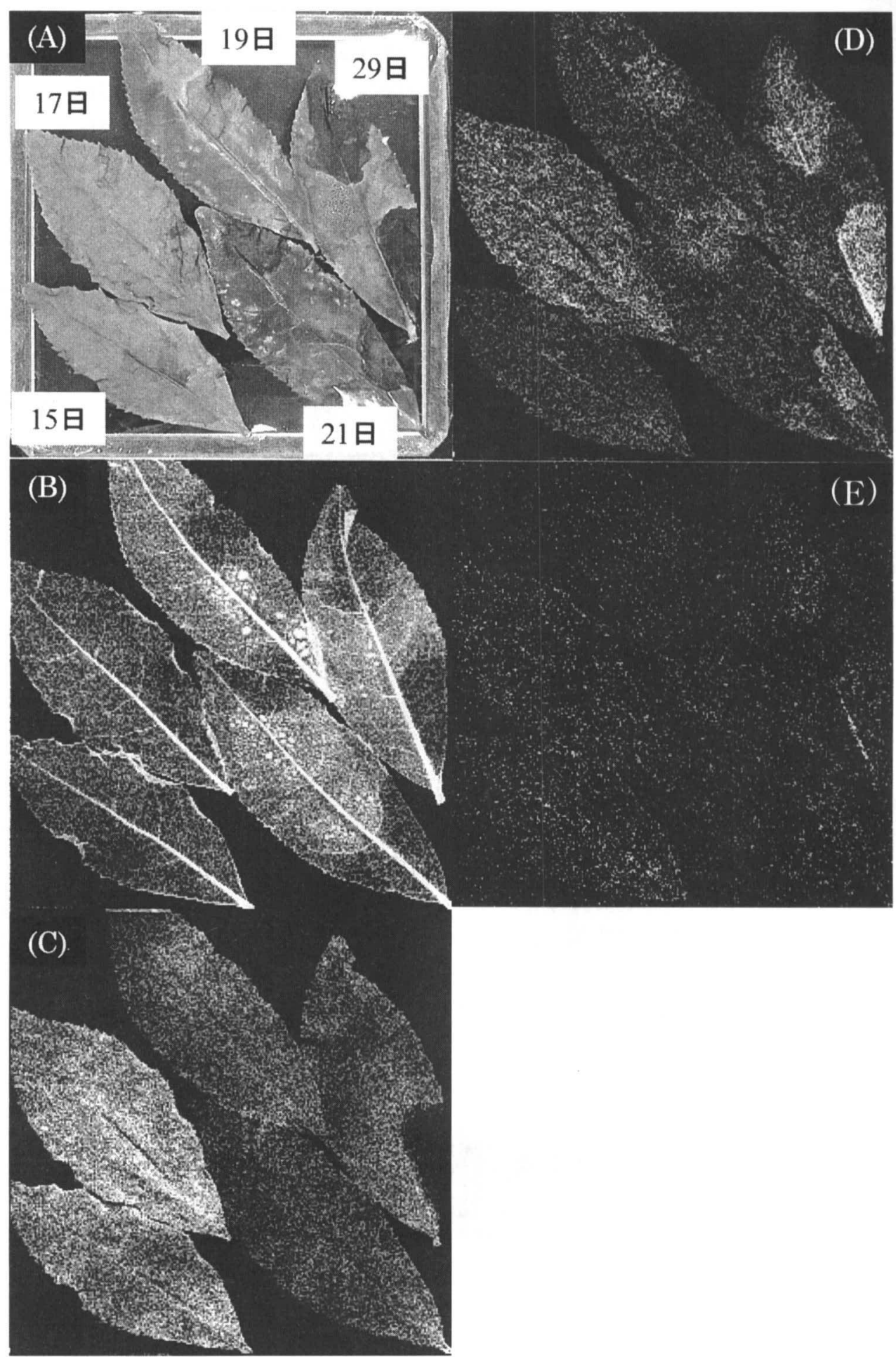

図 4 炭素病罪病葉における病斑拡大と蛍光 X線マッピング画像による各元素の動態 (A) 炭素病䍜病葉写真 (写真中の日数は炭そ病菌接種からの日数) (B) X線透過像

(C)カリウムのマッピング画像 (D)カルシウムのマッピング画像 (E)マンガンのマッピング画像 *各マッピング画像は白色の濃い部分により多くの元素が分布していることを表す。 


\section{4 摘 要}

蛍光 X線分析顕微鏡を用いた茶葉の無機元 素分析について検討した。その結果，カリウ 么は成葉, 新葉の全体に存在し, 新芽の心に やや多くみられた。また，カルシウムは成葉 や大きな新葉に多く存在し, 特に葉柄に多く 存在していた。

この方法を用いて，チャ炭疽病に罹病した 茶葉の無機成分を分析したところ，カルシウ ムは次第に炭疽病特有の壊死病斑部に集積 し, 逆にカリウムは病斑部から消失していっ た。炭疽病による壊死の進行とともに茶葉中 の無機元素が移行することが明らかとなっ た。

蛍光 X線分析顕微鏡による無機元素分析は 茶殺青葉および凍結乾燥茶葉中において，そ の存在部位とその動態を多元素同時に分析す ることが可能であり, 生理障害, 病虫害など に対する茶樹の反応を解明するうえで有用な 方法であることが明らかとなった。

\section{5 謝辞}

炭疽病, 蛍光X線分析法の茶への利用につ いて御助言下さった独立行政法人食品総合研 究所流通安全部長永田忠博博士，並びにポッ 卜育苗した茶苗を提供下さった静岡県茶業試 験場育種研究室長（現静岡県農業水産部お茶 室専門監)中村順行氏に厚く御礼申し上げる。

\section{6 引用文 献}

1) Watanabe,H. and Y. KobAyashi
(1986): X-Ray Induced Transport of Inorganic Elements in Living Rice Leaves Observed with X-Ray Fluorescence Element Mapping Spectrometry. Agric.Biol.Chem.50(8),2077-2082.

2 ）渡辺久男 (1990)：蛍光X線マッピング装 直による植物モニタリング技法の開発， ぶんせき $2 ， 155-161$.

3 ）石垣幸三(1978)：茶樹の栄養特性に関す る研究，茶試研報№.14，134-142。

4 ）小西茂樹(1991)：茶樹の栄養生理. 村松 敬一郎編, 茶の科学, 朝倉書店, pp.21-32

5 ) 三輪悦夫 - 高柳博次 -中川致之 (1978) : 葉位別にみた茶葉の化学成分含量, 茶研 報№.47，48-52

6 ）池谷賢次郎 (1991)：茶の化学成分量とそ の含有量. 村松敬一郎編, 茶の科学, 朝 倉書店, p p . 91-92.

7 ）永田忠博 (1994）：茶葉成分の特徵。岩浅 潔編著, 茶の栽培と利用加工, 養賢堂, pp. 37-44

8) 永田忠博 (1990)：新しい分析法による茶 の品質に係わる成分の研究，茶研報№.72， 53-58

9）池谷賢次郎・高柳博次・阿南豊正(1990)： 茶の分析法，茶研報№.71，43-74.

10）安藤康雄・浜屋悦次（1986）：于ャ炭そ病 菌の侵入に対する宿主の抵抗反応，茶技 研No.69，35-43. 